\title{
Molecular Characterization of the S-alleles and Compatibility among Hybrid Pear Tree Cultivars for Subtropical Regions
}

\author{
Rayane Barcelos Bisi, Rafael Pio, Daniela da Hora Farias, \\ and Guilherme Locatelli \\ Department of Agriculture, University of Lavras, 37200-000, Lavras, MG, \\ Brazil
}

Caio Morais de Alcântara Barbosa

Department of Plant Science, University of São Paulo, 13418-900, Piracicaba, SP, Brazil

\section{Welison Andrade Pereira \\ Department of Biology, University of Lavras, 37200-000, Lavras, MG, Brazil}

Additional index words. Pyrus, Rosaceae, S-allele, self-incompatibility

\begin{abstract}
Pear (Pyrus spp.) is a temperate-climate fruit species that has gametophytic selfincompatibility. Cross-pollination among intercompatible cultivars can be useful in selecting for breeding programs. The objective of the present study was to evaluate effective fruiting from cross-pollination between hybrid pear cultivars and to characterize pear tree S-alleles. Seven cultivars were evaluated: Cascatense, Centenária, D'água, Primorosa, Seleta, Tenra, and Triunfo. Controlled crosses were carried out in two seasons and consisted of spontaneous self-pollination, parthenocarpy, and crosspollination between cultivars. During the 2 years of research, the overlap of the entire flowering periods of all cultivars was higher than $50 \%$. Phenology was evaluated from the beginning of pruning, and the time elapsed from pruning to the flowering phenophase was computed. Finally, the flowering-period overlap of the cultivars was analyzed. Salleles were characterized by polymerase chain reaction (PCR) using primers specific to previously known alleles. Under field conditions, the Primorosa cultivar has high potential as a pollinizer for D'água, Seleta, Tenra, and Triunfo. Pear tree hybrid cultivars have a high frequency of the S1 and S5 alleles. The S5S8 and S1S4 alleles are amplified in the D'água and Seleta cultivars, respectively, conferring compatibility between these cultivars. The $\mathrm{S} 1$ and $\mathrm{S} 5$ alleles are amplified in 'Primorosa', 'Cascatense', and 'Triunfo', conferring interincompatibility.
\end{abstract}

The pear tree (Pyrus spp.) is a temperateclimate fruit species, and its cultivation in subtropical regions was made possible by hybrid cultivars obtained from the cross Pyrus communis $\times$ Pyrus pyrifolia (Curi et al., 2017). This cross combines the quality of European pear trees (P. communis) with the low number of chill hours required by the Asian pear tree (P. pyrifolia) (Chagas et al., 2008).

Low fruit set is one of the limiting factors in the expansion of pear tree crops in subtropical regions (Bettiol Neto et al., 2014). The fact that no pollinizer cultivars have been reported for these hybrids in subtropical re-

Received for publication 10 June 2019. Accepted for publication 3 Sept. 2019.

This study was financed in part by CAPES Finance Code 001, CNPq (Process: 425001/ 2018-0), and FAPEMIG, as well as the UFLA for providing the structure for carrying out the study. D.d.H.F. is the corresponding author. E-mail: dhorafarias@gmail.com. the incompatibility between cultivars may be misleading due to environmental and physiological effects that hinder differentiation between fully compatible and semicompatible crosses. Therefore, the use of another method to increase the reliability of the evaluation is crucial; such a method includes the analysis of genes encoding for S-RNase to identify the S-loci in cultivars, which can define the compatibility level between cultivars, complementing and corroborating the results observed in the field (Jacquemart, 2007).

Self-incompatibility based on S-RNase occurs in Rosaceae species. Compatibility is controlled by the polymorphic S-locus, which encodes at least two genes. S-RNases determine the specificity of pollen rejection in the pistil, and the F-locus and F-box proteins fulfill this function in pollen. SRNase is believed to function as a specific $\mathrm{S}$ cytotoxin and as a recognition protein. Thus, the incompatibility is a consequence of the cytotoxic activity of S-RNase. Conversely, SRNase cytotoxicity does not occur in compatible pollen tubes (McClure et al., 2011).

Pear breeding programs are carried out in cold regions and seek to develop cultivars adapted to these climatic conditions, with high-yield performance, which fit in the fresh fruit chain. However, pear tree exploitation in subtropical (Bettiol Neto et al., 2014) and tropical regions (Oliveira et al., 2015) has increased. In this sense, breeding programs for cultivars adapted to regions with high temperatures must be intensified.

This study aimed to characterize S-alleles in hybrid pear cultivars ( $P$. communis $\times P$. pyrifolia) adapted to subtropical climates and evaluate the effective fruiting from the cross between these cultivars.

\section{Materials and Methods}

The experiments were conducted in Lavras, MG, Brazil (lat. $21^{\circ} 14^{\prime} \mathrm{S}$; long. $45^{\circ} 00^{\prime} \mathrm{W}$; altitude $841 \mathrm{~m}$ above sea level), in the 2015 and 2016 seasons. The climate of the study region is classified as Cwa (subtropical climate, with cold and dry winter and hot and humid summer) (Souza et al., 2017). This study used seven $P$. communis $\times P$. pyrifolia cultivars: Cascatense, Centenária, D'água, Primorosa, Seleta, Tenra, and Triunfo (Table 1).

Pear cultivars were grafted on the Pyrus calleryana L. rootstock and transplanted into the field in Oct. 2010, spaced $3 \mathrm{~m}$ between rows and $4 \mathrm{~m}$ of row distance (density of 833 plants/ha). Pears were conducted in "central leader" system.

Phenological stages and field crosses were evaluated in the Fruiticulture Sector of UFLA in seven different pear cultivars (Table 1). The phenological stages were evaluated in 2015 and 2016, and the crosses were analyzed in the 2015-16 and 2016-17 seasons.

Climatic variables and flowering phenology. The time elapsed between the phenophases of each cultivar was recorded from the beginning of pruning. The beginning, the 
end, and the duration of flowering were verified and the overlap of the flowering periods was analyzed. These data were correlated with climatic variables during the experimental period and used to compare the flowering period between cultivars. Figure 1 shows the climatic data for the period.

Molecular analysis. For the molecular analysis of the cultivars (Table 1), completely expanded, healthy, young leaves from adult plants were collected in 2016 in the field and stored in Styrofoam boxes containing ice until storage in an ultrafreezer. The DNA extraction protocol was adapted from Doyle and Doyle (1987). Initially, $2 \mathrm{~g}$ of leaf tissue was macerated in liquid nitrogen. Then, 10 $\mathrm{mL}$ of cetyl trimethylammonium bromide (CTAB) extraction buffer $[2 \%$ CTAB, $100 \mathrm{~mm}$ TRIS (pH 8.0), $1.4 \mathrm{M} \mathrm{NaCl}$, and $1 \%$ polyvinylpyrrolidone] was added to each sample, the suspension was transferred to a 50-mL falcon tube, and the set was incubated in a water bath at $65^{\circ} \mathrm{C}$ for $30 \mathrm{~min}$. During this period, the macerated material was homogenized every $10 \mathrm{~min}$. The first DNA extraction was performed by adding chloroform:isoamyl alcohol at a ratio of $24: 1$ to a volume of $10 \mathrm{~mL}$. The centrifuge tube was gently shaken to homogenize the suspension. At this stage, the organic and aqueous phases were separated by centrifugation at 10,000 rpm for $5 \mathrm{~min}$. The supernatant was collected, for DNA extraction. Samples were identified

and the remainder was discarded. Afterward, the nucleic acids were precipitated in a mixture of $30 \mathrm{~mL}$ of $95 \%$ alcohol: $7.5 \mathrm{M}$ ammonium acetate $(6: 1)$ for $24 \mathrm{~h}$ in a freezer $\left(-20{ }^{\circ} \mathrm{C}\right)$. After precipitation, the nucleic acids were transferred to microcentrifuge tubes and centrifuged again. The supernatant was discarded, and the pellet was placed at room temperature for drying. Then, the nucleic acids were hydrated in TE buffer (1 mM TRIS and 0.1 mm EDTA). In the second extraction, phenol:chloroform:isoamyl alcohol (25:24:1) was added. The organic and aqueous phases were separated by centrifugation at $14,000 \mathrm{rpm}$ for $5 \mathrm{~min}$. The supernatant was transferred to a $2-\mathrm{mL}$ microtube. In a new tube, chloroform:isoamyl alcohol was added to the aqueous phase at a ratio of $24: 1$, followed by centrifugation. The supernatant was collected and transferred to a new 2-mL microtube and precipitated by adding three volumes of a mixture of $3 \mathrm{M}$ sodium acetate:95\% ethanol (1:20) for at least 1 hour in the freezer $\left(-20{ }^{\circ} \mathrm{C}\right)$. After DNA precipitation and drying, the material was hydrated in TE buffer and quantified in a ultraviolet-Vis Nanodrop ND-1000 spectrophotometer (NanoDrop Technology, Rockland, DE). The quantified material was diluted in pure water to a concentration of $10 \mathrm{ng} / \mu \mathrm{L}$ and then used in the PCR.

PCR and gel electrophoresis. PCRs were adapted from Sanzol et al. (2006) using the

Table 1. List of cultivars with their respective identification number, genealogy, and origin information.

\begin{tabular}{llll}
\hline Identification & Cultivar & \multicolumn{1}{c}{ Genealogy } & \multicolumn{1}{c}{ Origin } \\
\hline 1 & Cascatense & Packham's Triumph $\times$ Le Conte & Embrapa - Brazil \\
2 & Centenária & Hood $\times$ Packham's Triumph & IAC - Brazil \\
3 & D'água & Unknown & Unknown \\
4 & Primorosa & Hood Packham's Triumph & Embrapa - Brazil \\
5 & Tenra & Madame Sieboldt $\times$ Packham's Triumph & IAC - Brazil \\
6 & Triunfo & Hood $\times$ Packham's Triumph & IAC - Brazil \\
7 & Seleta & Hood $\times$ Packham's Triumph & IAC - Brazil \\
\hline
\end{tabular}

IAC $=$ Agronomic Institute of Campinas.

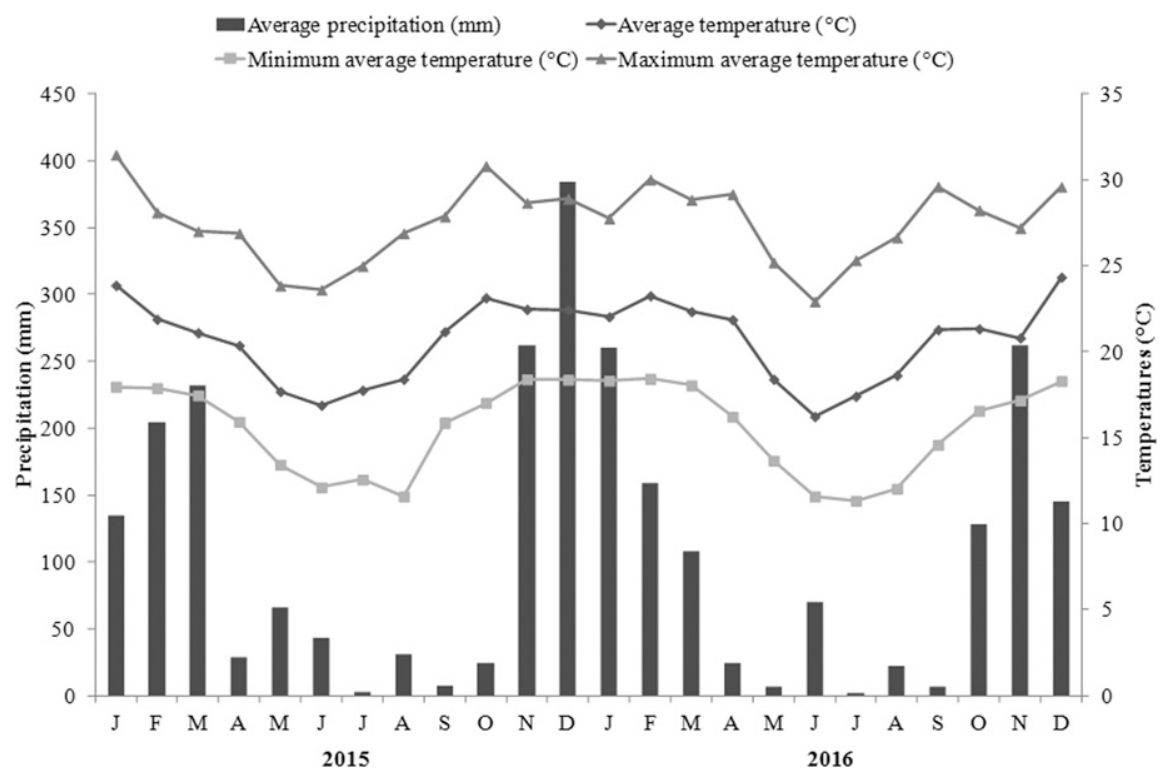

Fig. 1. Climatic data from January 2015 to December 2016. Lavras, Minas Gerais, Brazil. primers shown in Table 2. Each reaction was composed of $50 \mathrm{ng}$ genomic DNA, $0.2 \mathrm{~mm}$ deoxyribonucleotide triphosphate, $50 \mathrm{~mm}$ Tris- $\mathrm{HCl}, 20 \mathrm{~mm} \mathrm{KCl}, 0.6 \mu \mathrm{M}$ of each primer, $2 \mathrm{~mm} \mathrm{MgCl}_{2}, 1 \mathrm{U}$ of Taq polymerase (Invitrogen, Carlsbad, CA), and ultrapure water to complete the $25 \mu \mathrm{L}$ total volume. The primers MPyC1F and MPyC5R were used to amplify the S-RNase products associated with the S1, S3, S4, and S5 alleles, and the S1 and S2 alleles were amplified using the reverse primer PycomS2R, as reported by Sanzol et al. (2006). The primers PycomC1F and PycomS2R (5' gtaatggttcttgtctattattgtgg $\left.3^{\prime}\right)$ were used to amplify other alleles, as described by Sanzol and Robbins (2008). The sequences of these primers are shown in Table 2.

Amplifications were performed in a thermocycler (2720; Applied Biosystems, Foster City, CA) programmed for a denaturation cycle of $2 \mathrm{~min}$ at $94{ }^{\circ} \mathrm{C}$, followed by 36 cycles of $30 \mathrm{~s}$ at $94{ }^{\circ} \mathrm{C}, 1 \mathrm{~min}$ at specific annealing temperature (Table 2), $2 \mathrm{~min}$ at $72{ }^{\circ} \mathrm{C}$, and a final extension at $72{ }^{\circ} \mathrm{C}$ for 10 min, after this procedure, samples were held at $4{ }^{\circ} \mathrm{C}$. Amplified DNA fragments were subjected to electrophoresis on $2 \%$ agarose gel, stained with ethidium bromide $(0.5 \mathrm{mg}$ / $\mathrm{mL})$, and immersed in $1 \times$ TBE buffer $(45 \mathrm{~mm}$ Tris-borate, $1 \mathrm{~mm}$ EDTA) for $3 \mathrm{~h}$ at $80 \mathrm{~W}$. The molecular weight marker was 100 base pairs (bp) DNA Ladder (Ludwig Biotec, Rio Grande Do Sul, Brazil).

Controlled crosses. Controlled crosses were carried out in the 2015-16 and 201617 seasons. Because there were different flower stages in the same umbrella, flowers were thinned by selecting only five flowers at the balloon stage per umbrella. Different treatments were performed in each of the seven cultivars before anthesis (Fig. 2):

1. Spontaneous self-pollination, during which five flowers of each umbrella were bagged;

2. Parthenocarpy, during which five flowers of each umbrella were emasculated and bagged;

3. Manual cross-pollination between cultivars, during which flowers were emasculated and pollinated by each of the other cultivars and then bagged.

Each treatment had seven replications with five flowers per experimental plot. Effective fruiting was evaluated $30 \mathrm{~d}$ after treatment installation. During the harvest, the number of fruits of each treatment was counted again. Field data cannot distinguish between completely compatible and semicompatible crosses because, in some cases, parthenocarpy may occur. Therefore, fruits with nonviable seeds were not considered for fruit set.

\section{Results and Discussion}

Climatic variables and flowering phenology. The flowering period of the cultivars varied among seasons, resulting in slight differences between 
Table 2. Primers used for the determination of S-alleles in pear tree cultivars (Pyrus sp.), with their respective nucleotide sequences.

\begin{tabular}{|c|c|c|c|c|}
\hline Primers & Sequences $\left(5^{\prime} \rightarrow 3^{\prime}\right)$ & Direction & Annealing temp $\left({ }^{\circ} \mathrm{C}\right)$ & Reference \\
\hline$\overline{\mathrm{MPyC} 1 \mathrm{~F}}$ & attattwtcaatttacgcakcartatcag & Forward & $52^{\circ} \mathrm{C}$ & Sanzol et al. (2006) \\
\hline MPyC5R & caaakasyrayctcracyaattcmg & Reverse & & \\
\hline PycomC1F & attttcaatttacgcagcaatatcagc & Forward & $54^{\circ} \mathrm{C}$ & Sanzol and Robbins (2008) \\
\hline PycomS2R & gtaatggttcttgtctattattgtgg & Reverse & & \\
\hline MPyC1F & attattwtcaatttacgcakcartatcag & Forward & $50^{\circ} \mathrm{C}$ & Sanzol et al. (2006) \\
\hline PycomS2R & gtaatggttcttgtctattattgtgg & Reverse & & \\
\hline
\end{tabular}
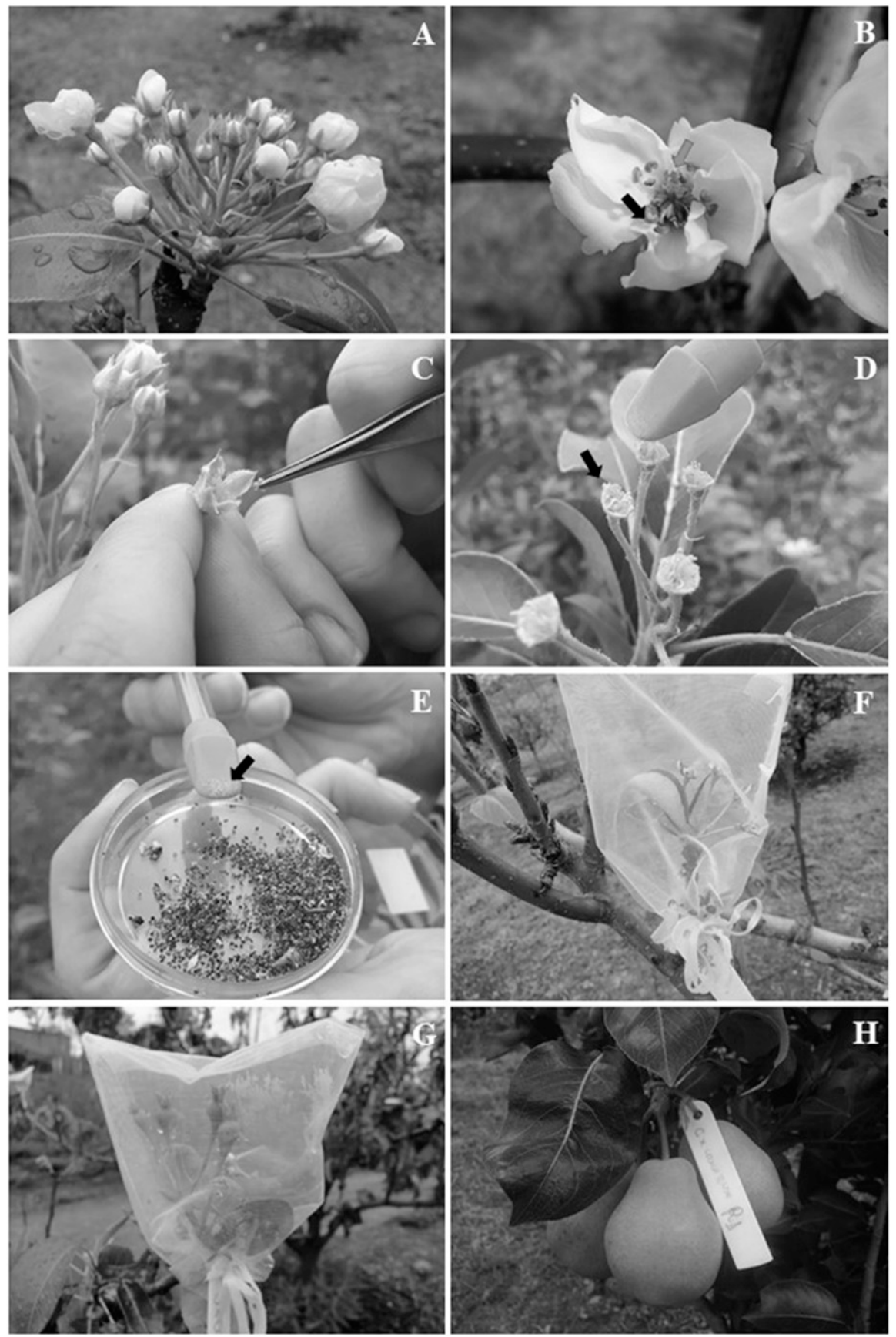

Fig. 2. Conduction of the experiment at different stages of the pear flower, cultivar Cascatense. (A) Inflorescence with pre-anthesis flowers. (B) Flower at anthesis: wet stigma (red arrow) and anthers (black arrow) (flowers at anthesis were removed). (C) Flower emasculation. (D) Emasculated flowers, only with the pistil. (E) Petri dishes with pollen (black arrow) for pollination. (F) Emasculated and pollinated flowers wrapped in organza. (G) Fruits at the beginning of the development stage. (H) Fruits at the final development stage. plants and within each growing season. The beginning of the flowering period was delayed when compared with the previous productive cycle (Fig. 3). This phenomenon may be directly related to environmental factors, as observed in Fig. 1. In 2015, greater rainfall occurred in February and March than in other months; in 2016, a considerable amount of rainfall occurred in June. Moreover, based on the average temperatures of the 2 years, relatively low temperatures, followed by an increase in temperature in 2015 , were anticipated in 2014 and 2015 compared with 2016. Together, these factors may have influenced the early flowering in 2015. Castro et al. (2016), in a study on apple trees, also observed that the full bloom period of some cultivars was delayed in years with a low number of chill hours. The same was observed in the present study in 2016.

During the 2 years of research, the overlap between the entire flowering periods of cultivars was higher than $50 \%$. The flowering progression was not uniform between cultivars, and at least two flowering peaks were observed in each cultivar during the flowering period (data not shown). In mild-winter regions, the chill hours and the temperature during the flowering period were the main factors affecting (directly or indirectly) the performance of pollination and fruiting (Soltész, 2003).

Molecular analysis. The combination of the MPyC1F/MPyC5R primers (Fig. 4A) allowed the amplification of three distinct alleles (S1, S4, and S5), and four of the seven cultivars studied had at least one of these three alleles. The PCR amplification products of these primers indicated that the cultivars Seleta, Primorosa, and Cascatense had the 1300-bp fragment associated with the S1 allele, whereas cultivar Seleta also had the 750 -bp product associated with the $\mathrm{S} 4$ allele. 'D'água' had the S5 allele associated with the 650 -bp product. The primer pair $\mathrm{MPyC} 1 \mathrm{~F} /$ PycomS2R (Fig. 4B) allowed detection of the S1 allele, with a 1150-bp fragment, in four of the evaluated cultivars (Triunfo, Seleta, Primorosa, and Cascatense). The combination of the PycomC1F/PycomS2R primers (Fig. 4C) allowed the amplification of three different $\mathrm{S}$ alleles (S1, S5, and S8). The sizes of these alleles, according to the visualization of the amplification results, ranged from 650 to 1300 bp. The S1 allele, with a 1300-bp fragment, was detected in 'Triunfo', 'Seleta', 'Primorosa', and 'Cascatense'. The S5 allele, with a 650-bp fragment, was found in 'Cascatense', 'Centenária', 'D’água', 'Primorosa', 'Tenra', and 'Triunfo'. The S8 allele, characterized by a 675 -bp product, was detected only in cultivar D’água.

Four different S-alleles were detected in the seven evaluated cultivars. Their PCR products ranged from 650 to $1300 \mathrm{bp}$. In general, when these primers were used, high frequencies of the S5 and S1 alleles were detected; the former was present in six cultivars, and the latter was found in four cultivars. 
According to Crane and Lewis (1942), in the past, gametophytic incompatibility between pear tree cultivars was unusual, and therefore, the expression of S-alleles was seldom investigated in comparison with other fruit trees. However, Sanzol and Herrero (2002) believe that the limited number of parents used in pear tree breeding programs could have increased the frequency of incompatibility between new cultivars.

Sanzol et al. (2006) also explained the high frequencies of S1 and S5 alleles. The

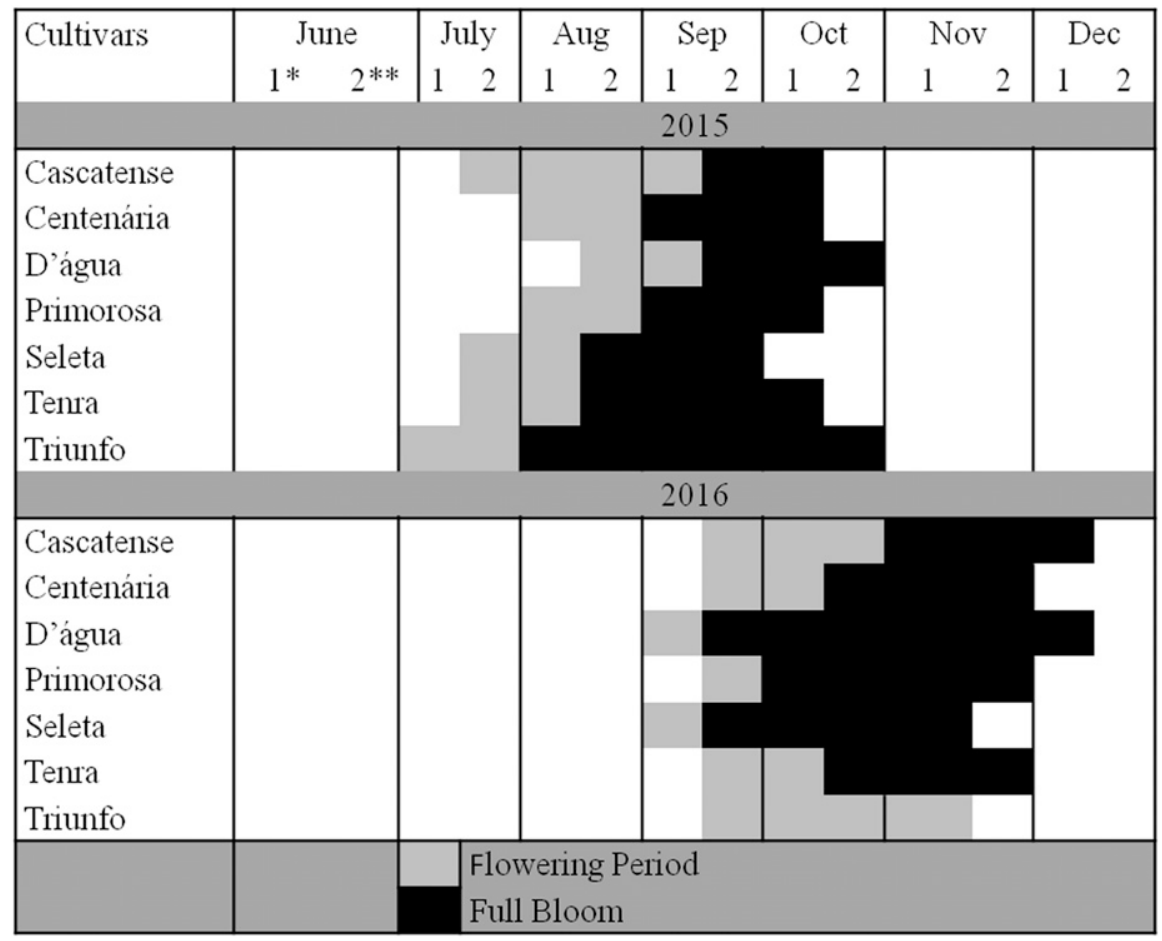

Fig. 3. Flowering period of cultivars in 2015 and 2016. *Indicates the first fortnight of the month ** Indicates the second fortnight of the month. authors confirmed that, in a breeding program of European pear trees, cultivars Williams (S1S2), Coscia (S3S4), and Doyenne du Comice (S4S5) are predominantly used as parents, and as a result, the S1 and S5 alleles are expected to be represented at higher frequencies.

The presence of the S1 allele in hybrid pear trees can be explained by the genealogy of the cultivars, because all of the cultivars have a common parent, that is, Packham's Triumph. Sanzol and Robbins (2008) ob- served the expression of S1 and S3 alleles in this cultivar. The S-alleles of the other parents are unknown.

Only cultivars Seleta (S1S4) and D'água (S5S8) showed intercompatibility (Fig. 3). All the other studied hybrids had at least one S-allele in common, conferring partial or total incompatibility to these plants. This phenomenon may hinder the selection of pollinizer cultivars for subtropical regions and compromise the fruit set and yield of these genotypes.

Mota et al. (2010) stated that the analysis of S-alleles, based on the PCR, has a high potential to be used in the identification of groups of self-incompatible cultivars. The knowledge of the S-alleles responsible for gametophytic incompatibility and the identification of an S-allele that can suppress this incompatibility will allow the controlled transfer of this alleles between cultivars with flowering synchrony. This capability will increase the efficiency of breeding programs in obtaining new cultivars and facilitate the reproductive management of orchards, aiming to improve fertilization and fruit set.

Cultivars Cascatense, Primorosa, and Triunfo showed the same PCR products when the three different primers were used. These results suggest that the three cultivars are incompatible. In fact, among the seven cultivars evaluated, Cascatense, Primorosa, and Triunfo were the only ones that showed total incompatibility between each other.

'Centenária' and 'Tenra' showed only the amplification product corresponding to the S5 allele. Yamane et al. (2003), in a study of cherry tree, almond tree, and apricot tree genotypes, also observed variations in the number of alleles between loci, as well as the absence of PCR products in some cultivars. This result, in some cases, can be justified by the occurrence of only one allele or null alleles for a given locus. Null alleles are
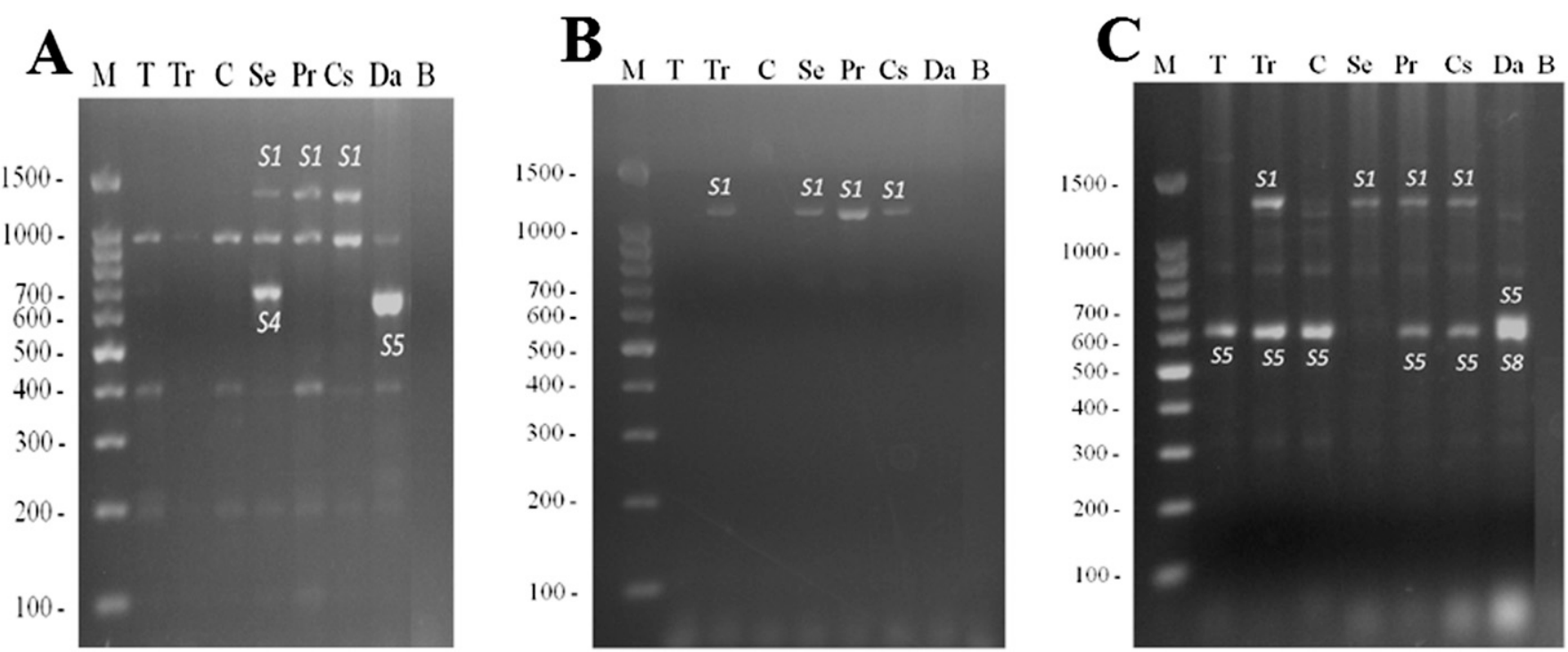

Fig. 4. Polymerase chain reaction amplification of S-alleles obtained from the primers combinations: (A) MPyC1F/MPyC5R; (B) MPyC1F/PycomS2R; and (C) PycomC1F/PycomS2R. M = 100 bp molecular marker, $\mathrm{T}=$ Tenra, $\mathrm{Tr}=$ Triumph, $\mathrm{C}=$ Centenária, $\mathrm{Se}=\mathrm{Seleta}, \mathrm{Pr}=\mathrm{Primorosa}, \mathrm{Cs}=\mathrm{Cascatense}, \mathrm{Da}=\mathrm{D}$ 'água, $\mathrm{B}=$ Branco. 
Table 3. Compatibility between seven different pear cultivars, based on the S-alleles.

\begin{tabular}{llccccccc}
\hline S-allele & Cultivars & Cascatense & Centenária & D’água & Primorosa & Seleta & Tenra & Triunfo \\
\hline S1 $\times$ S5 & Cascatense & SI & SC & SC & I & I & SC & SC \\
S5 & Centenária & SC & SI & SC & SC & SC & SC & SC \\
S5 $\times$ S8 & D’água & SC & SC & SI & SC & SC & SC & SC \\
S1 $\times$ S5 & Primorosa & I & SC & SC & SI & I & SC & SC \\
S1 $\times$ S4 & Seleta & SC & SC & SC & I & SI & SC & SC \\
S5 & Tenra & SC & SC & SC & SC & SC & SI & SC \\
S1 $\times$ S5 & Triunfo & I & SC & SC & I & SC & SC & SI \\
\hline
\end{tabular}

$\mathrm{SI}=$ self-incompatible cross; $\mathrm{SC}=$ semicompatible cross; $\mathrm{I}=$ incompatible cross

Table 4. Percentage of fruit set obtained from the self-pollination, crosses, and parthenocarpy of seven pear tree cultivars.

\begin{tabular}{lcccccccc}
\hline & \multicolumn{10}{c}{ Receptor } \\
\cline { 2 - 8 } Pollinizer & Cascatense & Centenária & D'água & Primorosa & Seleta & Tenra & Triunfo & Parthenocarpy \\
\hline Cascatense & 0.00 & 60.00 & 24.00 & 8.00 & $\mathrm{np}$ & $\mathrm{np}$ & $\mathrm{np}$ & 28.00 \\
Centenária & 46.67 & 0.00 & 42.00 & 42.67 & $\mathrm{np}$ & $\mathrm{np}$ & $\mathrm{np}$ & 26.67 \\
D’água & 14 & 14.00 & 0.00 & 36.00 & $\mathrm{np}$ & $\mathrm{np}$ & $\mathrm{np}$ & 1.33 \\
Primorosa & 0 & 18.67 & 26.67 & 0.00 & $\mathrm{np}$ & $\mathrm{np}$ & $\mathrm{np}$ & 2.67 \\
Seleta & 57.33 & 44.00 & 50.00 & 60.00 & 17.33 & $\mathrm{np}$ & $\mathrm{np}$ & 14.67 \\
Tenra & 44 & 0.00 & 38.67 & 69.33 & $\mathrm{np}$ & 0.00 & $\mathrm{np}$ & 21.33 \\
Triunfo & 23.33 & 56.00 & 12.00 & 53.33 & $\mathrm{np}$ & $\mathrm{np}$ & 14.00 & 16.00 \\
\hline
\end{tabular}

$\mathrm{np}=$ nonpollinated (no pollination was performed due to the lack of pollinizer cultivars).

Table 5. Data of fruit set percentage and viable seeds percentage from the self-pollination of seven pear tree cultivars.

\begin{tabular}{lcc}
\hline Self-pollination & Fruit set $(\%)$ & Viable seeds $(\%)$ \\
\hline Cascatense & 18.00 & 0.00 \\
Centenária & 36.67 & 0.00 \\
D’água & 0.00 & 0.00 \\
Primorosa & 17.33 & 0.00 \\
Seleta & 17.33 & 16.00 \\
Tenra & 10.67 & 0.00 \\
Triunfo & 14.00 & 8.00 \\
\hline
\end{tabular}

described in several microsatellite systems and are the result of mutations such as substitutions, insertions, and deletions in one or both annealing regions of the primers in a homologous sequence of template DNA (Callen et al., 1993).

According to the amplification patterns of the S-alleles in the studied cultivars, Cascatense, Primorosa, and Triunfo were incompatible with each other. Cultivars D'água and Seleta were compatible. All the other cultivars were semicompatible with each other (Table 3).

Controlled crosses. Based on the field pollination results (Table 4), cultivars Cascatense, Centenária, D’água, Primorosa, and Tenra showed self-incompatibility. All the fruits harvested had unviable seeds. These fruits were considered parthenocarpic and were therefore not counted as selfpollinated fruits. Conversely, the selfpollinated cultivars Seleta and Triunfo showed fruits with viable seeds, with fruit set percentages of $17.33 \%$ and $14.0 \%$, respectively (Table 5). This is an interesting characteristic for crops that have selfincompatibility. No pollinizers are required when cultivars with self-incompatibility breakdown are grown. This self-compatibility may be related to environmental factors or mutations; however, when more than $30 \%$ of all flowers are fertilized, the cultivar is considered self-compatible (Ishimizu et al., 1998).
The fruit set resulting from the selfpollination of Seleta and Triunfo may be related to the concentrations of S-RNAses in their flower style. The high total concentration of S-RNAses in the style controlled by the two $\mathrm{S}$-alleles in each cultivar prevents pollen tube growth and effective fruiting, justifying the occurrence of cultivars with different selfincompatibility levels (Hiratsuka and Zhang, 2002; Zhang and Hiratsuka, 1999).

In addition, high $\left(20\right.$ to $\left.25^{\circ} \mathrm{C}\right)$ or low $(15$ to $20^{\circ} \mathrm{C}$ ) temperatures during the flowering stage may induce self-fertility by the deactivation or inhibition of the S-locus, which causes insufficient production of RNases (Nyéki, 1996). This phenomenon possibly occurs due to the insertion of several $\mathrm{CH} 3 \mathrm{~s}$ in the region that promotes the $\mathrm{L}$ receptor, consequently blocking the transcription of the $\mathrm{S}$ gene (Pancaldi, 1995). Furthermore, this phenomenon allows self-pollination between genotypes that have two identical Salleles of gametophytic incompatibility, with the consequent formation of few viable seeds and low fruit set ( $1 \%$ to $5 \%)$. High (20 to $\left.25^{\circ} \mathrm{C}\right)$ or low $\left(15\right.$ to $\left.20^{\circ} \mathrm{C}\right)$ temperatures also can increase the percentage of parthenocarpic fruits (i.e., fruits without seeds) (Lombard, 1990). Thus, it may be unclear which of these two processes occurs if the formation or nonformation of viable seeds is not observed, because, in most of the Brazilian regions where pear trees are cultivated, average temperatures higher than $16^{\circ} \mathrm{C}$ are commonly recorded during the flowering stage.

According to Sassa (2016), S-locus products are not sufficient to determine selfincompatibility in Rosaceae species, and other factors not linked to S-loci can also influence self-incompatibility. Some of these factors have already been identified in other species, such as the mutation of part of the pollen in sweet cherry (Cachi and Wünsch, 2011). Therefore, further studies are required to elucidate self-compatibility in Rosaceae species.

When flowers are self-pollinated and produce seedless fruits, the process is designated as stimulative parthenocarpy (Moriya et al., 2005). According to Crane and Lewis (1942), sterility and self-incompatibility, which prevent self-pollination of pear flowers, may be hindered by stimulative parthenocarpy.

Regarding the fruit set data (Table 5), cultivar Centenária, despite being selfincompatible ( $0 \%$ of viable seeds), had a fruit set higher than 30\%. Kozma et al. (2003) argue that the application of sterile pollen stimulates stigmatic secretion, which triggers reactions in the ovary, stimulating fruit development and preventing the formation of abscission tissue at the base of the fruit peduncle, which will grow without developing viable seeds. Jackson (2005) found that pollination, even without fertilization, stimulates the cytoplasmic and biochemical activity of the pistil and the development of the ovary and thus increases the viability of the embryo sac. Tomimoto et al. (1996) reported an example of stimulative parthenocarpy, in which the cross between different cultivars with the same allelic series generated high fruit set due to the induction of stimulative parthenocarpy, mainly in cultivars with high potential to express this trait.

When the parthenocarpy method was evaluated, 'Cascatense', 'Centenária', and 'Tenra' showed a fruit set higher than 20\%; 'Seleta' and 'Triunfo' had a fruit set higher than 10\%; and 'D'água' and 'Primorosa' had a fruit set lower than 5\%. According to Jalili Marandi (2002), when $5 \%$ to $8 \%$ of pear tree flowers are converted into fruits, the yield is considered economically acceptable. Parthenocarpy is the production of fruits without seeds and ovule fertilization. This process is desirable in several fruit trees that show incompatibility because it may reduce many problems associated with pollination, such as the need for manual pollination or pollinator insects. However, physical or chemical stimuli are usually required for fruit development and formation (Nishitani et al., 2012).

The crosses 'Tenra' $\times$ 'Primorosa' (69.3\%), 'Seleta' $\times$ 'Primorosa' (60\%), 'Cascatense' $\times$ 'Centenária' $(60 \%)$, 'Seleta' $\times$ 'Cascatense' (57.3\%), 'Triunfo' $\times$ 'Centenária' $(56 \%)$, 'Triunfo' $\times$ 'Primorosa' (53.3\%), and 'Seleta' $\times$ 'D'água' $(50 \%)$ had fruit set percentages equal to or higher than $50 \%$. The cross 'Tenra' $\times$ 'Primorosa' stood out for showing the highest fruit set.

Cultivars Seleta and D'água were compatible in relation to the $\mathrm{S}$-allele series; these cultivars also showed high fruit set in the crosses carried out in the field. In addition, semicompatible cultivars showed high fruit set. The fact that fully compatible cultivars did not have a fruit set of $100 \%$ can be explained by other aspects involved in this process, such as the availability and viability of the pollen grains of the pollinizer cultivar.

'Primorosa', when used as the receptor, showed low fruit set (lower than 30\%) regardless of the pollinizer. However, when 
used as a pollinizer for 'Seleta', 'Tenra', and 'Triunfo', cultivar Primorosa showed the best fruit set performance in the evaluated crosses, despite being semicompatible, according to the S-allele results (Table 3 ).

'Cascatense', when pollinated by 'Primorosa', showed a fruit set of only $8 \%$. The reciprocal cross showed a $0 \%$ fruit set and was considered incompatible. This result corroborates the PCR results, because both analyses showed the S1 and S5 alleles.

'Triunfo', when pollinated by 'Cascatense', showed $23 \%$ fruit set and was considered incompatible. When pollinated by 'Primorosa', cultivar Triunfo had high fruit set $(53 \%)$, mainly because these cultivars showed incompatibility when the S-alleles were molecularly identified as S1 and S5.

Sanzol et al. (2006) stated that physiological and environmental factors might influence cultivar compatibility. Wojciechowski and Antkowiak (2009), working with pear cultivars in different environments, observed that some crosses were incompatible in the laboratory and greenhouse but compatible in the field. Hiratsuka and Tomita (1989) observed reduced expression of self-incompatibility in pear trees under high-temperature conditions and at different flower development stages. The present results suggest that the high fruit set of the 'Triunfo' $\times$ 'Primorosa' cross occurred due to the relatively high temperatures at the experimental site.

Future experiments with crosses of 'Triunfo' under controlled environments are necessary to detect whether the incompatibility breakdown is related to extrinsic or intrinsic factors because even the selfincompatibility was broken down. If this phenomenon is related to high temperatures, 'Triunfo' is a promising cultivar for mildwinter regions. However, if the breakdown is due to intrinsic factors, such as S-allele mutations, the cultivar is advantageous for pear tree breeding programs that seek self-compatible cultivars. Although selfcompatibility is beneficial to genetic diversity, it is unfavorable to agriculture. Thus, self-compatible mutants, particularly selfincompatible commercial fruit species, have been exploited in agricultural production (Mase et al., 2014).

Centenária showed a fruit set ranging from $42 \%$ to $46 \%$, and the fruit set percentage of this cultivar did not significantly vary in response to different pollinizers. 'D'água' showed low fruit set when pollinated by 'Cascatense' and 'Centenária' (14\%) and a fruit set of $36 \%$ when pollinated by 'Primorosa'. Cultivar Tenra showed very high fruit set when pollinated by Primorosa, despite being semicompatible.

In general, when Seleta was used as a receptor, the cultivar showed high fruit set percentages varying from $44 \%$ to $60 \%$ in the crosses. This result shows that a high fruit set percentage dramatically influences the mother plant. In addition to the gametophytic incompatibility between cultivars, other factors inherent to pear plants also influence fruit set. The flowering period is one of the main events during the productive cycle of fruit tree species because fruiting is defined at this stage. During this period, environmental and physiological factors interact with each other, which defines the next fruiting and production stages.

The choice of pollinizer plants is based mainly on the coincidence of flowering, which does not always result in satisfactory yields due to incompatibility between cultivars. In addition to the physiological aspects evaluated, this strategy, which is associated with molecular characterization data of S-alleles, facilitates the understanding of the reproductive system and the choice of more compatible genotypes, both for use in breeding programs and in the establishment of orchards of this species (Bandeira et al., 2011).

\section{Conclusions}

Pear tree hybrid cultivars have high frequency of the S1 and S5 alleles.

Under field conditions, the cultivar Primorosa has high potential as a pollinizer for the cultivars D'água, Seleta, Tenra, and Triunfo.

Cultivars with relatively high fruit set are compatible and semicompatible.

Cultivar D'água amplifies the S5S8 alleles and Seleta amplifies the S1S4 alleles, conferring full compatibility to these plants.

Cultivars Primorosa, Cascatense, and Triunfo amplify the S1 and S5 alleles, conferring interincompatibility to these plants.

\section{Literature Cited}

Bandeira, J.M., L.B. Thurow, J.A. Peters, M.C.B Raseira, and V.J. Bianchi. 2011. Physiological characterization of reproductive compatibility of Japanese plum. Pesqui. Agropecu. Bras. 46:860-867.

Bettiol Neto, J.E., E.A. Chagas, J. Sanches, R. Pio, S. Antoniali, and P. Cia. 2014. Production and postharvest quality of pear tree cultivars in subtropical conditions at eastern of São Paulo state, Brazil. Cienc. Rural 44:1740-1746.

Cachi, A.M. and A. Wünsch. 2011. Characterization and mapping of non- $S$ gametophytic selfcompatibility in sweet cherry (Prunus avium L.). J. Expt. Bot. 62:1847-1856.

Callen, D.F., A.D. Thompson, Y. Shen, H.A. Phillips, R.I. Richards, J.C. Mulley, and G.R. Sutherland. 1993. Incidence and origin of "null" alleles in the (AC) in microsatellite markers. Amer. J. Hum. Genet. 52:922-927.

Castro, D.C., M.C. Cerino, N. Gariglio, and S. Radice. 2016. Study of reproductive behaviour in low-chill apples in warmer zones of Argentina. Scientia Hort. 199:124-132.

Chagas, E.A., F.A. Campo Dall'Orto, M. Ojima, W. Barbosa, and R. Pio. 2008. Pear 'IAC Princesinha': New European type cultivar for subtropical climate. Acta Hort. 800:507-510.

Crane, M.B. and D. Lewis. 1942. Genetical studies in pears III. Incompatibility and sterility. J. Genet. 43:31-44.

Curi, P.N., R.B. Bisi, D.L. Salgado, C.M.A. Barbosa, R. Pio, and V.R. Souza. 2017. Hybrid cultivars of pear in subtropics regions: Processing ability in the form of jelly. Cienc. Rural $47: 1-7$.
Doyle, J. J. and J.L. Doyle. 1987. A rapid DNA isolation procedure for small quantities of fresh leaf tissue. Phytochem. Bull. 19:11-15.

Franklin-Tong, N.V. and F.C. Franklin. 2003. Gametophytic self-incompatibility inhibits pollen tube growth using different mechanisms. Trends Plant Sci. 8:598-600.

Goldway, M., O. Shai, H. Yehuda, A. Matityahu, and R.A. Stern. 1999. 'Jonathan' apple is a lower-potency pollenizer of 'Topred' than 'Golden Delicious' due to partial S-allele incompatibility. J. Hort. Sci. Biotechnol. 74:381385 .

Hiratsuka, S. and A. Tomita. 1989. Incompatible pollen tube growth and protein composition in styles of Japanese pear following high temperature treatments. Euphytica 43:191-196.

Hiratsuka, S. and S.L. Zhang. 2002. Relationships between fruit set, pollen-tube growth, and S.RNase concentration in the selfincompatible Japanese pear. Scientia Hort. 95:309-318.

Ishimizu, T., Y. Sato, T. Saito, Y. Yoshimura, S. Norioka, T. Nakanishi, and F. Sakiyama. 1998. Identification and partial amino acid sequences of seven S-RNases associated with selfincompatibility of japanese pear, Pyrus pyrifolia Nakai. J. Biochem. 120:326-334.

Jackson, J.E. 2005. Biology of apples and pears. Cambridge University, Cambridge.

Jacquemart, A.L. 2007. Methods for determining compatibility and pollinator efficiency in temperate fruit species. Fruit. Vegetable and Cereal Science and Biotechnology. 1:26-38.

Jalili Marandi, R. 2002. Pomology. Jahad Daneshgahi, Oromiye, Iran.

Kozma, P., J. Nyéki, M. Soltész, and Z. Szabó 2003. Floral biology, pollination and fertilisation in temperate zone fruit and grape. Akadémiai Kiadó, Budapest.

Lombard, P.B. 1990. Principales cultivos y nuevas variedades de peras en USA. Revista de Fruticultura. 5:241-256.

Mase, N., Y. Sawamura, T. Yamamoto, N. Takada, S. Nishio, T. Saito, and H. Iketani. 2014. A segmental duplication encompassing S-haplotype triggers pollen-part self-compatibility in Japanese pear (Pyrus pyrifolia). Mol. Breed. 33:117-128.

Mahmoudi, M., K. Arzani, and N. Bouzari. 2007. Pollination, pollen tube growth and determination of suitable pollinizer for sweet cherry (Prunus avium L.) cultivar Ghermez Rezaeieh. Majallah-i Bih/Nizhadi-i Nahal va Bazr 23:571-585.

McClure, B., F. Cruz-García, and C. Romero. 2011. Compatibility and incompatibility in SRNase-based systems. Ann. Bot. 108:647-658.

Moriya, Y., Y. Takai, K. Okada, D. Ito, Y Shiozaki, T. Nakanishi, and T. Takasaki. 2005. Parthenocarpy and self- and crossincompatibility in ten European pear cultivars. J. Jpn. Soc. Hort. Sci. 74:424-430.

Mota, M.S., V.J. Bianchi, A.Z. Carvalho, E.J.B Braga, and J.A. Peters. 2010. Molecular identification of s-alleles of gametophytic incompatibility in Prunus salicina Lindl. Rev. Bras. Frutic. 32:798-807.

Nishitani, C., A. Yamaguchi-Nakamura, F. Hosaka, S. Terakami, T. Shimizu, K. Yano, and T. Yamamoto. 2012. Parthenocarpic genetic resources and gene expression related to parthenocarpy among four species in pear (Pyrus spp.) Scientia Hort. 136:101-109.

Nyéki, J. 1996. Fertilization conditions, p. 185256. In: J. Nyéki and M. Soltész (eds.). Floral biology of temperate zone fruit trees and small fruits. Akadémiai Kiadó, Budapest, Hungary.

Oliveira, I.V.M., S. Matos, R.R. Salustriano, and P.R.C. Lopes. 2015. Phenology evaluation of 
'triumph' pear trees grown in semi-arid climate in the northeast Brazil in 2012 season. Rev. Bras. Frutic. 37:261-266.

Ortega, E. and F. Dicenta. 2004. Suitability of four different methods to identify self-compatible seedlings in an almond breeding programme. J. Hort. Sci. Biotechnol. 79:747-753.

Pancaldi, M. 1995. Aspects of the genetics of the gametophytic incompatibility in the sterility of fruit plants. Rivista di Frutticoltura e di Ortofloricoltura. 58:70-75.

Sanzol, J. and M. Herrero. 2002. Identification of self-incompatibility alleles in pear (Pyrus communis L.) cultivars. Euphytica 128:325-331.

Sanzol, J., B.G. Sutherland, and T.P. Robbins. 2006. Identification and characterization of genomic DNA sequences of the S-ribonuclease gene associated with self-incompatibility alleles S1 to S5 in European pear. Plant Breed. 125:513518.

Sanzol, J. and T.P. Robbins. 2008. Combined analysis of S-alleles in European pear by pollinations and
PCR-based S-genotyping; correlation between S-phenotypes and S-RNase genotypes. J. Amer. Soc. Hort. Sci. 133:213-224.

Sassa, H. 2016. Molecular mechanism of the SRNase-based gametophytic selfincompatibility in fruit trees of Rosaceae. Breed. Sci. 66:116121.

Souza, F.B.M., R. Pio, J.P.R.A.D. Barbosa, G.L. Reighard, M.H. Tadeu, and P.N. Curi. 2017. Adaptability and stability of reproductive and vegetative phases of peach trees in subtropical climate. Acta Sci. Agron. 39:427-435.

Soltész, M. 2003. Apple [Malus sylvestris L. Mill.], p. 237-316. In: P. Kozma, J. Nyéki, M. Soltész, and Z. Szabó (eds.). Floral biology, pollination in temperate zone fruit species and grape. Akadémiai Kiadó, Budapest, Hungary.

Tatari, M., A. Ghasemi, A. Mousavi, and H. Bahrami. 2017. Study on pollination and selection of the most suitable pollinizers for commercial pear cultivars (Pyrus communis L.) in Iran. J. Hort. Res. 25:49-57.
Tomimoto, Y., T. Nakazaki, H. Ikehashi, H. Ueno, and R. Hayashi. 1996. Analysis of self-incompatibilityrelated ribonucleases (S-RNases) in two species of pears, Pyrus communis and Pyrus ussuriensis. Scientia Hort. 66:159-167.

Wojciechowski, A. and W. Antkowiak. 2009. Selection of pollinators for particular pear cultivars (Pyrus communis L.) based on the observation of the pollen tubes. Herba Polonica Journal 55:257-265.

Yamane, H., K. Ikeda, K. Ushijima, H. Sassa, and R. Tao. 2003. Self-incompatibility (S) locus region of the mutated S6-haplotype of sour cherry (Prunus cerasus) contains a functional pollen $S$ allele and a non-functional pistil $S$ allele. J. Expt. Bot. 54:2431-2437.

Zhang, S.L. and S. Hiratsuka. 1999. Variations in S-protein levels in styles of Japanese pears and the expression of self-incompatibility. J. Jpn. Soc. Hort. Sci. 68:911-918. 